ISSN: 2146-3042

DOI:10.25095/mufad.828513

\title{
Finansal Katılım Düzeyi ve Belirleyicileri Üzerine Ampirik Bir Araştırma: Türkiye Örneğiं*
}

\author{
Abdul Musawer RAHIMYAR** \\ Suna AKTEN ÇÜRÜK***
}

\section{ÖZET}

Finansal katılım, bir ekonominin tüm üyeleri için resmi finansal sisteme erişimi, kullanılabilirliği ve kullanım kolaylı̆̆ını să̆layan bir süreci ifade eder. Finansal katılım, finansal sistemin istikrarında, ekonomik ve sosyal büyümede, işsizliğin ve yoksulluğun azaltılmasında, yoksulların gelirinin artırılmasında, gelir eşitsizliğinin azaltılmasında ve kadınların ekonomik olarak güçlendirilmesinde önemli bir role sahiptir. Finansal katılım düzeyi, bir ülkede ilgili politikaların ve stratejilerin etkisi ile sürekli değișen bir olgudur. Bu araștırmayla, Türkiye'deki finansal katılım mevcut durumunun incelenmesi ve finansal katılım düzeyi belirleyicilerinin ortaya konması amaçlanmaktadır. Araştırmada, veriler 480 kişiye uygulanan anket yöntemi ile elde edilip, tanımlayıcı istatistikler ve probit regresyonu kullanılarak analiz edilmiştir. Elde edilen sonuçlara göre, ankete katılanlar arasında finansal katılımının temel göstergesi olan hesap sahipliği oranı \%89.8'dir. Tasarruflar daha çok resmi bir banka hesabı kullanılarak yapılmaktadır. Aile, akraba ve arkadaşlardan borç alma yöntemi bankalardan daha yaygındır. Finansal katılımının diğer bir göstergesi olan sigorta hizmetlerinden yararlananların yüzdesi 69.8'dir. Regresyon analizi sonucu olarak, bireylerin gelir ve eğitim düzeyi, resmi hesap sahipliği ve resmi tasarruflar ile anlamlı bir ilişkiye sahiptir. Ayrıca bireylerin yaşı ve hesap sahipliği arasında da pozitif bir ilişsi bulunmaktadır.

Anahtar Kelimeler: Finansal katılım, Finansal Erişim ve Türkiye'de Finansal Dışlanma.

JEL Sinıflandırması: D14, P45

\begin{abstract}
An Empiric Research on Level and Determinants of Financial Inclusion: The Case of Turkey

\section{ABSTRACT}

Financial inclusion refers to a process that provides access, availability and ease of use to the formal financial system for all members of an economy. Financial participation has an important role in the stability of the financial system, economic and social growth, reducing unemployment and poverty, increasing the income of the poor, reducing income inequality and empowering women economically. The level of financial participation is a constantly changing phenomenon in a country with the effect of relevant policies and strategies. This study aimed to evaluate the current situation of financial inclusion and its determinants in Turkey. The data was obtained through questionnaires from 480 people and analyzed using the descriptive analysis method and Probit regression. According to the obtained results, the account ownership rate is 89.8\% as the main indicator of financial inclusion. Using a formal account to save money and borrowing from family or friends are common. The percentage of insurance services users, which is another indicator of financial inclusion, is 69.8. As a result of regression analysis, individuals' income and education level significantly affect account ownership and formal savings. There is also a positive relationship between the age of individuals and account ownership.
\end{abstract}

Keywords: Financial Inclusion, Financial Access and Financial Exclusion in Turkey.

Jel Classification: D14, P45.

\footnotetext{
* Bu çalışma, Necmettin Erbakan Üniversitesi İşletme Yüksek Lisans Programında tamamlanan "Türkiye ve Afganistan Özelinde Ülkeler Arası Finansal İçerme Durumu Karşılaştırması” isimli yüksek lisans tezinden yararlanılarak hazırlanmış ve 9. İstanbul Finans Kongresi'nde özet bildiri olarak sunulmuştur.

Makale Gönderim Tarihi: 26.11.2020, Makale Kabul Tarihi: 20.02.2021 , Makale Türü: Nicel Araştırma

** Necmettin Erbakan Üniversitesi, İşletme Bölümü, abdul.musawer443@gmail.com, ORCID: 0000-0003-04086414.

*** Dr. Öğr. Üyesi, Necmettin Erbakan Üniversitesi, İşletme Bölümü, sakten@erbakan.edu.tr, ORCID: 00000001-5887-4905.
} 


\section{GİRIŞ}

Finansal katılım (FK), bir ekonominin tüm üyeleri için resmi finansal sisteme erişimi, kullanılabilirliği ve kullanım kolaylığını sağlayan bir süreci ifade eder (Sarma ve Pais, 2011: 613). Dünya Bankası finansal katılımı, bireylerin ve işletmelerin, ihtiyaçlarını karşılayan, sorumlu ve sürdürülebilir bir şekilde sunulan uygun fiyatlı ve yararlı finansal hizmetlere (tasarruf, kredi, ödeme, banka işlemleri ve sigorta) erişim olarak ifade etmektedir (www.worldbank.org, 2019). Bu tanım içeriği bakımından beş temel finansal hizmetten söz etmektedir. Bunlar; tasarruflar, krediler, ödemeler, banka işlemleri ve sigortadır. Finansal katılım, Türkçe literatürde, finansal içerme, finansal kapsama ve finansal tabana yayılma ile eşanlamlı ifadeler olarak kullanılmaktadır. Finansal katılım kelimesinin İngilizce literatürde karşılığı "Financial Inclusion" dır.

Finansal katılım, finansal sistemin istikrarında, ekonomik ve sosyal büyümede, işsizliğin ve yoksulluğun azaltılmasında, yoksulların gelirinin artırılması ve gelir eşitsizliğinin azaltılmasında ve kadınların ekonomik olarak güçlendirilmesinde önemli bir role sahiptir (AlSmadi, 2018: 31; Chibba, 2009:213; Swamy, 2014:14). Finansal katılımının arttırılmas1, yastık altı tasarrufların harekete geçirilmesine, sermaye oluşumuna ve ekonominin büyümesine, toplumun geniş kısmının gereksinimlerinin karşılamasına (finansal sistem geliştirmesine), sosyal ve politik hedeflere hizmet eder (Sharma ve Kukreja, 2013: 16).

Finansal katılımın amacı, toplumun zayıf ve düşük gelire sahip olan bölümlerine bankacılık ve diğer temel finansal hizmetleri, örneğin; tasarruf hesapları, kredi kolaylıkları ve sigorta hizmetlerini zamanında ve yeterli miktarda sağlamak (Iqbal ve Sami, 2017: 646); banka hesabı olmayan kitleyi resmi finansal sisteme çekmek ve böylece onlara finansal hizmetlere (tasarruf, ödemeler, havale, kredi, sigorta vb. hizmetlere) erişim imkânı sunmaktır (Hannig ve Jansen, 2010: 1).

Global Findex (2017) veri tabanına göre, dünya genelinde 1.7 milyar kişi bir finansal kuruluşta veya mobil para aracılığıyla bir işlem hesabına sahip değildir ve banka dışı kalan kitle olarak tanımlanmaktadır. Finansal katılım düzeyi, gelişmiş ülkelerde yüksek olduğu için hesabı olmayanların çoğu gelişmekte olan ülkelerde bulunmaktadır (Demirguc-Kunt vd., 2018: 4). Aynı veri tabanına göre, 2017'de Türkiye'de bireylerin \% 76's1 resmi bir finansal kurum veya mobil para hesabına sahiptir. Bu oran, 2017 yılında Türkiye'de yetişkin bireylerin \% 24'ünün banka dışı kaldığını göstermektedir.

Dünya genelinde son zamanlarda, özellikle küresel finansal kriz sonrasında, politikacılar, düzenleyiciler, araştırmacılar ve pazar uygulayıcıları için finansal katılım, artan bir ilgi konusu haline gelmiştir. Türkiye'de finansal ürün ve hizmetleri toplumun tüm kesimlerine yaymak, finansal açıdan dışlanmış olanları finansal sisteme çekmek ve mevcut ürün ve hizmetlerin kalitesini ve kullanımını artırmak için bütüncül bir yaklaşım benimsenmiştir. Ülkemizde finansal erişim, finansal eğitim ve finansal tüketicinin korunması 2014'te bir strateji olarak ilgili organizasyonlar tarafından düzenlenmiştir (Başbakanlık, 2014:2). Ayrıca Hazine Müsteşarlığı'nın 2014 - 2018 yıllarına ilişkin Stratejik Planı'nda; finansal sistemi ve finansal istikrarı güçlendirmek için finansal ürün ve hizmetlerde çeşitliliğin, derinliğin ve finansal katılımın arttırılmasının amaçlandığı ifade 
edilmektedir.(Başbakanlık Hazine Müsteşarlığı,2014:9). Benzer şekilde Bankacılık Düzenleme ve Denetleme Kurumu'nun 2019-2021 Dördüncü Stratejik Planı'nda finansal katılımı etkileyen hedefler yer almaktadır (BDDK, 2019: 4,5). Devlet stratejilerine ek olarak, finansal katılım düzeyini artırmayı hedefleyen diğer faaliyetler Finansal Okuryazarlık ve Erişim Derneği (FODER) tarafından yapılmaktadır. Bu kurum Türkiye'de, yerel ve ulusal düzeyde toplumsal kalkınmayı desteklemek amacıyla, bireylerin finansal okuryazarlık ve para yönetimi konusundaki yeterliliğini arttırmak ve etkili finansal kararlar almak için faaliyetlerini yürütmektedir (www.fo-der.org, 2019).

Finansal katılım düzeyinin arttırılmasını hedefleyen stratejilerin, politikaların ve diğer faktörlerin etkisinden dolayı FK düzeyi sabit bir konu değil sürekli değișen bir olgudur. Yani her ekonomide zaman içinde finansal katılım düzeyi ve finansal katılımı etkileyen faktörler (belirleyicileri) de değişmektedir. Bu çalışmada, Türkiye'deki finansal katılım mevcut durumunun ortaya konması ve finansal katılım düzeyi belirleyicilerinin tespit edilmesi amaçlanmaktadır. Araştırmada bu hedeflere ulaşmak için, veriler, uygulanan online (çevrimiçi) anket yöntemi ile elde edip, verileri analiz etmek için tanımlayıcı istatistikler ve Probit regresyon analiz metodu olarak kullanılmıştır. $\mathrm{Bu}$ çalışma bulguları, literatüre Türkiye'deki finansal katılımının güncel durumu hakkında bilgi sağlayarak, geçmiş politikalar için bir değerlendirme ölçütü olmasının yanı sıra; gelecek için etkili ve daha uygun politikaların oluşturmasına da katkıda bulunmayı amaçlamaktadır. Bu çalışmada ilk olarak finansal katılıma ilişkin literatürü tarayıp ardından araştırmanın amacı, yöntemi, araştırma bulguları ve son olarak araştırma sonuç ve tartışma bölümü yer almaktadır.

\section{LITERATÜR TARAMASI}

Finansal katılım 21. yüzyılın başlarında ortaya çıkan bir kavram olarak ilk kez Birleşmiş Milletler tarafından 2005 yılında finansal sektörün mikro düzey ölçeği olarak tanıtılmıştır (Nasr, 2017: 16). Bu konuya ilişkin dünya çapındaki ilk çalışmalar çoğunlukla uluslararası organizasyonlar, örneğin Dünya Bankası ve Uluslararası Para Fonu (IMF), tarafından yapılmıştır. $\mathrm{Bu}$ olgunun önemi arttıkça, akademisyenler ve araştırmacılar tarafından gösterilen ilgi de artmıştır. Yapılan çalışmalardan bazıları bir ekonomideki finansal katılım düzeyinin belirlenmesine, bazıları ise finansal katılımın ana belirleyicilerinin anlaşılmasına odaklanmaktadır.

Türkiye'de finansal katılım düzeyi ve belirleyicilerinin tespiti ile ilgili literatür sadece birkaç çalışmayla sınırlıdır. Yorulmaz (2013) Türkiye'de finansal sistemin kapsamını ölçmeye yönelik, bir çalışma ile farklı bölge ve iller arasında karşılaştırmalar yapmak için 2004 ve 2010 dönemini kapsayan çok boyutlu bir finansal katılım endeksi geliştirmiştir. Bu araştırma sonuçlarına göre, Türkiye'nin farklı illerinde finansal katılım seviyeleri, gelir seviyeleri ile ilişkili olup, finansal katılım endeksi açısından İstanbul en yüksek ve Orta Doğu Anadolu illeri en düşük sıralarda yer almaktadır.

Terzi (2015), Türkiye'deki KOBİ'ler temelinde finansal katılım konusunda kaydedilen ilerlemeyi, arz tarafi, talep tarafı ve politika perspektiflerini göz önüne alarak analiz etmiştir. Terzi’ye göre, KOBİ'ler tarafından banka kredilerin kullanımı 2009 y1lından bu yana kadar sürekli artmaktadır. Yazar finansal hizmetlerin fiyat açısından uygun olmaması, yüksek kredi faiz oranları ve ağır ipotek şartlarına KOBİ'lerin finansmana erişiminde sınırlayıcı faktörler olarak değinmektedir. 
Gebeşoğlu (2015) Türkiye'deki finansal katılım düzeyini Dünya bankası tarafindan 2011 yılında yapılmış anket sonuçlarını ortaya koyan Global Findex (2011) veri setini kullanarak inceleyip, üst-orta gelirli ülkelerdeki finansal katılım düzeyi ile karşılaştırmıştır. Çalışma sonuçlarına göre, Türkiye'deki finansal katılım düzeyi üst-orta gelirli grupların ortalamasina göre düşüktür.

Korkmaz (2016), Türkiye'de finansal erişimin belirleyicileri üzerine bir model çalışması yapmıştır. Korkmaz, finansal sistemin arz taraflı verileriyle ilgili göstergeleri kullanarak Türkiye'de finansal erişim seviyesini ölçmüştür. Banka şube sayısının ve bu alanda meydana gelen artışların finansal erişim üzerinde arttırıcı; gelir düzeyinde meydana gelen artışların finansal erişim üzerinde azaltıcı etkide bulunduğunu tespit etmiştir.

Özşuca (2019) Türkiye'deki FK seviyesini inceleyip, bireylerin cinsiyeti, yaşı, gelir ve eğitim düzeyinin finansal katılımın kullanım ve bariyer boyutları üzerindeki etkisini değerlendirmiştir. Özşuca (2019) Global Findex (2017) veri setini kullanıp, ampirik analiz yöntemi olarak çok değişkenli Probit modeli uygulamıştır. Türkiye'de resmi bir hesaba sahip olan kişilerin yüzdesinin dünya ortalamasına yakın, gelişmekte olan ülkelerinin ortalamasından biraz yüksek ve birçok OECD üye ve üst-orta gelirli ülkelerinin yüzdelerinden düşük olduğuna değinmiştir. Ayrıca, gelir, eğitim ve yaşın FK göstergeleri ile pozitif ilişkili olduğu ve kadın olma değişkenin ise FK göstergeleri ile negatif ilişkili olduğu sonucuna varmıştır. Türkiye'de kişilerin bireysel özelliklerinin her birinin finansal katılımın önündeki engelleri açıklamada önemli olduğunu da belirtmiştir. Özşuca (2019)'ya göre, bireysel özellikler arasında cinsiyet, hesap sahipliğinin önündeki engelleri açıklamada en önemli özellik olarak ortaya çıkarken, yaşın sadece dini kaygıları etkilediği bulunmuştur. Türkiye ile ilgili bu iki çalışma incelendiğinde, ülkede kadın olmanın finansal katılımın ana göstergeleri üzerindeki olumsuz etkisinin 2011-2017 yılları arasında sürekli azaldığını ifade etmek mümkündür.

Karakuş (2020), Türkiye'deki finansal katılımının kapsamını değerlendirmeyi ve bireysel faktörlerin finansal katılım ile nasıl ilişkili olduğunu analiz etmeye çalışmıştır. Karakuş, Global Findex (2011) ve (2014) veri setlerini kullanıp, Probit regresyonu analiz yöntemini uygulamıştır. Araştırmaya göre 2014 yılında, 2011 yılına kıyasla, resmi bir banka veya diğer bir finansal kurumda tasarruf eden ve borç alan bireylerin yüzdesi artmıştır. Ancak bu kurumlarda hesabı olan yetişkinlerin oranı azalmıştır. Söz konusu yıllarda bireysel özellik olarak kadın olmanın, Türkiye'deki bir bankada veya diğer resmi finansal kurumlarda hesap sahibi olma, tasarruf etme ve bu kurumlardan borç alma olasılığının üzerinde olumsuz etkileri olduğu sonucuna varmıştır. Bu olumsuz etkinin 2014 yılında, 2011 yılına göre azaldığını belirlemiştir. Cinsiyetin finansal katılım üzerindeki etkisine ek olarak, diğer üç faktör; yaş, gelir ve eğitim düzeyi de finansal katılım üzerinde olumlu bir etkiye sahiptir. Karakuş (2020), yaşın finansal katılım ana göstergeleri üzerinde doğrusal olmayan etkisini de vurgulamaktadır.

Uluslararası literatüre bakıldığında benzer çalışmaların olduğu görülmektedir. Demirguc-Kunt ve Klapper (2012), Demirguc-Kunt vd. (2015) ve Demirguc-Kunt vd. (2018) Global Findex 2011, 2014 ve 2017 veri tabanlarının talep tarafı verilerini kullanarak; dünya çapında 140 'ten fazla ekonomide, finansal katılım düzeyini, yani; yetişkinlerin hesap sahipliği, tasarruf etme, kredi ve borç alma ve ödeme davranışlarını analiz etmişlerdir. 
Demirguc-Kunt vd. (2018), 2017 yılında dünya genelinde yetişkin bireylerin \% 68.5 'inin resmi bir finansal kurumda hesaba sahip olduğunu, \% 26.7'sinin resmi bir finansal kurumda tasarruf ettiğini ve \% 22.5'i resmi bir finansal kurumdan borç ve kredi aldığını bildirmişlerdir. Değinilmiş bu üç çalışma, genel olarak küresel finansal katılım düzeyini deskriptif bir şekilde analiz etmişlerdir.

Fungáčová ve Weill (2015), Çin'de finansal katılım derecesini analiz etmek ve diğer BRICS ülkeleriyle karşılaştırmak için Global Findex (2011) veri tabanından faydalanmıştır. Fungáčová ve Weill (2015) bireysel özelliklerin, finansal katılımının üç temel göstergesi (hesap sahibi olma, resmi tasarruf ve kredi) üzerindeki etkilerini belirlemek için Probit regresyon modelini kullanmışlardır. Bu çalışmanın ampirik analiz sonucu olarak; erkek, yaşlı, yüksek öğrenim ve yüksek gelir sahibi olmak Çin'de yüksek düzeyde finansal katılım neticesi vermiştir.

Tuesta vd. (2015), Arjantin'deki finansal katılım düzeyini anlamak için finansal katılımının çeşitli boyutlarını analiz etmişlerdir. Tuesta vd., kişinin bireysel özelliklerinin finansal katılım ve dışlanma ile nasıl ilişkili olduğunu anlamak için bir dizi Probit modelinden yararlanmıştır. Sonuçlara göre, bir kişinin yaşı, geliri ve eğitim düzeyi finansal hizmetleri kullanıp kullanmadığını etkileyen önemli faktörlerdendir. Ayrıca, yaş ve gelir düzeyinin, finansal katılımının önünde engel olarak algılanan iki sebep olduğu sonucuna varmışlardır.

Nandru vd. (2016), hesap sahipliği ve bankacılık hizmetlerinin kullanımı ile ölçülen finansal katılımının belirleyicilerini değerlendirmeye çalışmışlardır. Bu çalışmada, bireylerin cinsiyet, çalışma durumu, yaş, eğitim ve gelir düzeyi, bir bankadaki hesap sahipliğinin kapsamını anlamak için açıklayıcı değişkenler olarak kullanılmıştır. Yazarlar verileri Hindistan'ın Pondicherry bölgesinde yaşayan bireyler üzerinde yapılmış bir anket aracılığıyla elde edip analiz etmek için ikili lojistik regresyon modeli uygulamışlardır. Nandru, Byram ve Rentala (2016), açıklayıcı değişkenler arasında bireylerin gelir ve eğitim düzeyinin, hesap sahipliği üzerinde daha etkili olduğunu bulmuşlardır.

Bir ülkede finansal katılım düzeyini arttırmak için merkez bankalar başta olmak üzere farklı kurumlar, organizasyonlar ve politikacılar tarafindan finansal sistem ve finansal katılımı etkileyen politikalar ve stratejiler ele alınır. Bu politikaların ve stratejilerin sonucu olarak finansal katılım düzeyi sabit bir olgu olmayıp, zaman içerisinde değişen bir olgudur. Sunulan literatürde çalışmalar daha önceki yılların verileri üzerinden finansal katılım durumunu ortaya koymaktadır. Finansal katılım ile ilgili daha etkileyici stratejiler ve politikaları ele alınmak için finansal katılım mevcut durumunu yansıtan güncel bilgilere ihtiyaç vardır. Bu nedenle bu araştırma, Türkiye'deki finansal katılım mevcut durumunun incelenmesi ve finansal katılım düzeyi belirleyicilerinin tespit edilmesini amaçlanmaktadır. Ayrıca, bu araştırmada finansal katılımın diğer göstergelerine ek olarak ve incelenmiş literatürden farklı olarak sigorta hizmetlerinden de bahsedilecektir.

\section{VERİ VE YÖNTEM}

Çalışmada, Türkiye'deki mevcut finansal katılım düzeyini tespit etmek ve kişilerin bireysel özelliklerinin (cinsiyet, yaş, gelir ve eğitim düzeyi), banka veya diğer bir finansal 
kurumda hesap sahipliği, tasarruf etme, kredi alma, kredi kartı sahipliği ve sigorta hizmetlerden yararlanma ile nasıl ilişkili olduğunu belirlemek amacıyla birincil veriler, online (çevrimiçi) anket formları aracığıyla toplanmıştır. Online anket yapmanın nedeni, 2019'un sonlarında Çin'de başlayan ve tüm dünyaya yayılan ve hala devam eden Korona virüs (Covid 19) salgınıdır. Böyle bir durumda mülakat gibi diğer veri toplama yöntemleri ile verilerin toplanması riskli olduğu için uygun görülmemiştir. Bu yöntem ile elde edilen veriler sadece internete erişimi olan bireyler tarafından sağlanıp, internet erişimi olmayanları kapsamamakta ve araştırmanın bir sinırlılığını oluşturmaktadır.

Araştırmanın evrenini Türkiye'de bir banka hesabı açmak için asgari yaş şartını yerine getiren; yani on sekiz ve daha üst yaştaki bireyler (yetişkin nüfus) oluşturmaktadır ve 2019 yılsonu itibariyle 60.000 .000 kişi civarındadır. Ana kütleyi temsil edecek olan örneklem sayıs $\% 5$ hata düzeyinde 384 kişi olarak belirlenmiş̧ir. Çalışmada ankete katılanların sayısı 480 kişidir. Finansal katılım literatürünü dikkate alarak anket, hedef kitlenin demografik bilgilerine (cinsiyet, yaş, gelir, eğitim ve çalışma durumuna) ilaveten, finansal katılım ana göstergelerine (hesap sahipliği, resmi tasarruf ve resmi kredi), sigorta hizmetlerinin kullanımına, finansal katılımının önündeki engellere, mobil bankacilık ve internet bankacıllığına, bireylerin tasarruf ve kredi davranışlarına ait verileri içermektedir.

$\mathrm{Bu}$ araştırmada elde edilmiş veriler Stata 14.2 programından yararlanarak analiz edilmiştir. Finansal katılım durumu ve finansal katılımın önündeki engelleri anlamak için deskriptif analiz metodu (frekans ve yüzde tabloları ve şekillerin kullanması gibi) ve bireysel karakteristiklerin finansal katılım ana göstergeleri ile nasıl ilişkili olduğunu anlamak için Probit regresyon analiz yöntemi kullanılmıştır. Çalışmanın ana hipotezi şöyledir:

$\mathrm{H}_{1}=$ Bireysel özellikler, finansal katılım ana göstergelerini etkileyen faktörlerdir.

Probit regresyonda kullanılacak değişkenler aşağıda yer alan denklemde gösterilmiştir:

$$
\begin{aligned}
& \mathrm{FK}_{\mathrm{b}}=\mathrm{F}(\text { Cinsiyet } ; \text { Y Yaşb; Gelirb; Eğitim }) \ldots \ldots \ldots \ldots \ldots \ldots \ldots \ldots \ldots \ldots \ldots \ldots \ldots \ldots \ldots \\
& \mathrm{FK}_{\mathrm{b}}=\beta 1+\beta 2 \text { Cinsiyet }_{\mathrm{b}}+\beta 3 \text { Yaşb }+\beta 4 \text { Gelir }_{\mathrm{b}}+\beta 5 \text { Eğitim } \mathrm{b}+\varepsilon \ldots
\end{aligned}
$$

Bu modelde, 'FK' bağımlı değişkenler olarak hesap sahipliği, resmi tasarruf, resmi kredi, kredi kartı sahipliği ve sigorta hizmetlerini, 'b' bireylere ait indeksi ve $\beta$ Probit regresyon katsayısını gösterir. Bireylerin cinsiyet, yaş, gelir ve eğitim düzeyi bağımsız ve açıklayıcı değişkenler olarak kabul edilir.

\section{BULGULAR}

Finansal katılım düzeyini anlamak için bu olgunun ana göstergelerine ait veriler deskriptif (yüzdeler, şekiller ve tablolar) bir şekilde analiz edilecektir. Sonrasında probit regresyon sonuçları ortaya konacaktır. 


\subsection{Katılımcıların Demografik İstatistikleri}

Tablo 1'de görüleceği gibi; Türkiye'de toplam 480 kişi ankete katılmıştır. Katılımcıların \% 56.5'i erkek ve \% 43.5'i kadındır. Katılımcıların \% 4.4'ü ilköğretim veya alt1, \% 13.1'i ortaöğretim/lise ve \% 82.5'i yükseköğretim veya daha fazla yüksek düzeyde eğitim görmüşlerdir. Katılımcıların \% 33.7'si 2.000 TL altında, \% 36.8'i (2.000-5.000) arası, $\%$ 21.6's1 (5.001-10.000) aras1, \% 5.21'i (10.000-20.000) aras1 ve \% 2.5'i, 20.001 ve üzeri aylık ortalama gelirli bireylerdir. Katılımcıların \% 28.3'ü kamuda, \% 27.5'i özel sektörde çalışmakta, \% 7.1'i kendi işletmesinin sahibi, \% 13.1'i işsiz ve \% 24'ü öğrenci veya emeklidir. Yaş gruplarına göre, katılımcıların \% 35.2'si (18-25) yaş arası, \% 27.1'i (26-33) yaş arası, \% 15.6'sı (34-41) yaş arası, \% 11.9'u (42-49) yaş arası ve \% 10.2'si (50 ve üzeri) yaş arası gruplarında yer almaktadır.

Tablo 1. Katılımcıların Demografik Özellikler

\begin{tabular}{|c|c|c|c|c|c|}
\hline Cinsiyet & Sıklık & Yüzde & Çalışma Durumu & Sıklık & Yüzde \\
\hline Erkek & 271 & 56.5 & Kamuda çalışanlar & 136 & 28.3 \\
\hline Kadin & 209 & 43.5 & Özel sektörde çalışanlar & 132 & 27.5 \\
\hline Toplam & 480 & 100 & $\begin{array}{l}\text { Kendi işletmesinin / serbest } \\
\text { meslek sahibi }\end{array}$ & 34 & 7.1 \\
\hline Ĕgitim Düzeyi & & & İşsiz olanlar & 63 & 13.1 \\
\hline İlköğretim veya Altı & 21 & 4.4 & \multirow{2}{*}{ Öğrenciler / Emekliler } & \multirow{2}{*}{115} & \multirow{2}{*}{24} \\
\hline Ortaöğretim / lise & 63 & 13.1 & & & \\
\hline $\begin{array}{l}\text { Yükseköğretim veya Daha } \\
\text { Fazlası }\end{array}$ & 396 & 82.5 & \multirow[t]{2}{*}{ Toplam } & \multirow[t]{2}{*}{480} & \multirow[t]{2}{*}{100} \\
\hline Toplam & 480 & 100 & & & \\
\hline Aylık Ortalama Gelir & & & Yaş Grubu & & \\
\hline $2.000 \mathrm{TL}$ altında & 162 & 33.7 & $18-25$ & 169 & 35.2 \\
\hline 2.000-5.000 TL & 177 & 36.8 & $26-33$ & 130 & 27.1 \\
\hline $5.001-10.000 \mathrm{TL}$ & 104 & 21.6 & $34-41$ & 75 & 15.6 \\
\hline $10.001-20.000 \mathrm{TL}$ & 25 & 5.21 & $42-49$ & 57 & 11.9 \\
\hline 20.001 TL ve üzeri & 12 & 2.5 & 50 ve üzeri & 49 & 10.2 \\
\hline \begin{tabular}{|c|} 
Toplam \\
\end{tabular} & 480 & 100 & Toplam & 480 & 100 \\
\hline
\end{tabular}

\subsection{Finansal Katılımının Ana Göstergelerine Ait Tanımlayıcı Analiz Bulguları}

\subsubsection{Hesap Sahipliği ve Kullanımı}

Finansal katılım ana göstergelerinden biri; bireylerin bir banka veya diğer bir finansal kuruluşta hesap sahipliği oranıdır (Fungáčová ve Weill, 2015:198 ; Özşuca, 2019: 1384). Türkiye'de ankete katılan bireylerin hesap sahipliği oranı ve hesaplarını kullanım türü Şekil 1 'de gösterilmiştir. 

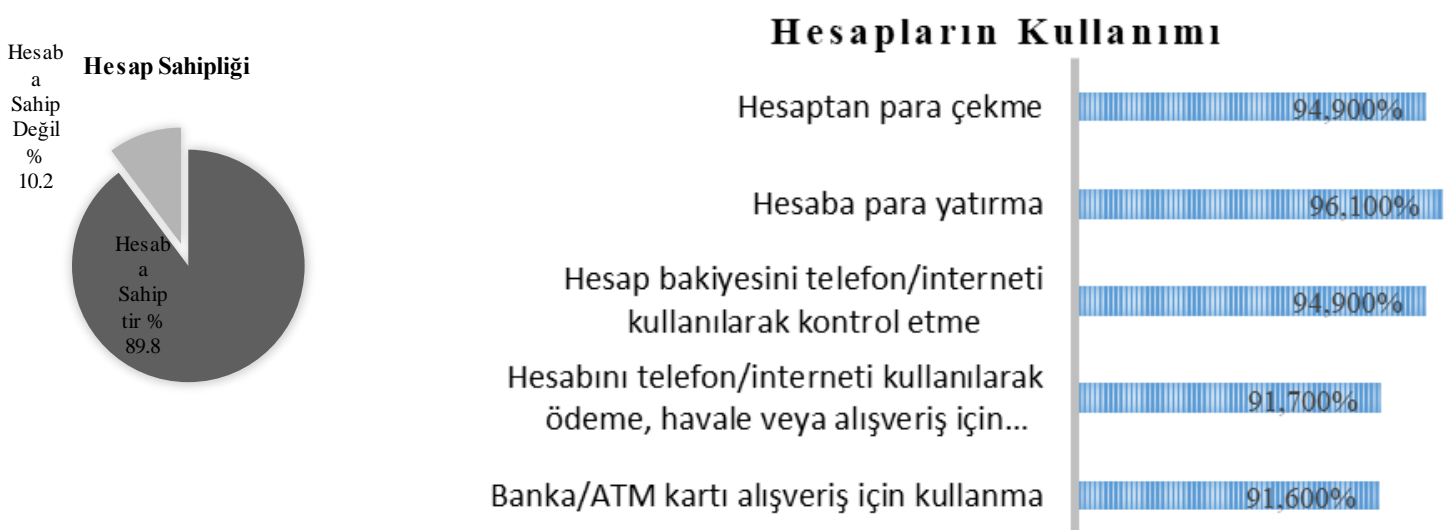

Şekil 1. Hesap Sahipliği ve Kullanımı

Şekil 1'de görüldügü gibi, anket katılımcılarının \% 89.8'i bir banka veya diğer bir finansal kuruluşta bir işlem hesabına sahip olduğunu bildirirken, \% 10.2'sinin bir hesab1 bulunmamaktadır. Türkiye'de yüksek düzeyde hesap sahipliği olması, bireylere diğer finansal hizmetlerden (tasarruf, kredi, havale, mobil bankacılık vb. gibi) yararlanmak için iyi bir ortam hazırlamıştır. Bir finansal kurumda, hesap sahibi olmak ve bu hesabı aktif olarak kullanmak finansal katılım açısından önemlidir. Dolaysıyla, Şekil 1'de gösterildiği gibi, ankete katılanlardan, hesap sahibi olanların çoğu (\% 90'dan fazlası) farklı şekillerde hesaplardan yararlanmaktadır. Örneğin, bir hesaba sahip olanların \% 96.1'i son 12 ayda1 hesaplarına para yatırıp \% 94.9'u hesaplarından para çekmişlerdir. Ayrıca bu bireyler (\% 90'dan fazlası) interneti, cep telefonu ve ATM kartını kullanarak ödeme, havale ve alışveriş için var olan hesaplardan yararlanmışlardır.

Tablo 2. Türkiye’de Hesap Sahipliği ve Bireysel Özelliklerine Göre Farklılı̆̆

\begin{tabular}{|c|c|c|c|}
\hline Hesap sahipliği Oranı & \multicolumn{3}{|c|}{$\% 89.8$} \\
\hline \multicolumn{4}{|c|}{ Bireysel Özelliklere Göre Hesap Sahipliği } \\
\hline Cinsiyete Göre & Yüzde & Çalışma Durumuna Göre & Yüzde \\
\hline Erkek & 91.5 & Kamuda çalışanlar & 96.3 \\
\hline Kadın & 87.6 & Özel sektörde çalışanlar & 94.7 \\
\hline Ĕgitime Göre & & Kendi işletmesinin sahibi & 88.2 \\
\hline İlköğretim veya altı & 42.9 & İşsiz olanlar & 65.1 \\
\hline Ortaöğretim / lise & 73 & Öğrenciler / Emekliler & 90.4 \\
\hline Yükseköğretim veya üstü & 94.9 & \multirow{3}{*}{ Yaş Grupları } & \\
\hline & & & \\
\hline Gelir Düzeyi Göre & & & \\
\hline 1. Gelir Kategori & 84.6 & $18-25$ & 91.1 \\
\hline 2. Gelir Kategori & 91 & $26-33$ & 93.8 \\
\hline 3. Gelir Kategori & 92.3 & $34-41$ & 89.3 \\
\hline 4. Gelir Kategori & 100 & $42-49$ & 93 \\
\hline 5. Gelir Kategori & 100 & 50 ve üstü & 71.4 \\
\hline
\end{tabular}

${ }^{1} \mathrm{Bu}$ çalışmada, verilerin analiz süresince değinilmiş “ “son 12 ay” 2020 Nisan ayını esas alınarak son 12 ayı ifade eder. 
Hesap sahipliği oranı, farklı bireysel özelliklere sahip bireyler arasında farklılık göstermektedir. Örneğin; erkekler, yüksek düzeyde eğitim görmüş bireyler, üst düzey gelirliler ve kamuda çalışanlar arasında hesap sahipliği oranı diğerlerine göre yüksektir. Bu özellikler (demografik çeşitliği) ve bunlara ait hesap sahipliği yüzdeleri Tablo 2'de gösterilmektedir. Türkiye' de kadınlar ve erkekler arasında hesap sahipliği açısından yüzde 3.9 puanlık bir boşluk var olup, ilköğretim veya alt eğitim düzeyine sahip olanlar ve üstteki eğitim düzeylerine sahip olanlar arasında büyük bir boşluk görülür. Hesap sahipliği oranı ilköğretim veya alt eğitim düzeyine sahip bireyler arasında \% 42.9 ve ortaöğretim veya lise düzeyinde eğitim görmüş bireyler arasında \% 73'tür, hâlbuki bu oran yükseköğretim veya üstü düzeyde eğitim görmüş bireyler arasında \% 94.9'dur. Gelir açısından sadece birinci kategoride yer alan (2.000 TL altında) bireylerin \% 84.6'sı bir banka veya diğer bir finansal kurumda hesaba sahipken diğer üst kategorilerde yer alan bireyler arasında hesap sahipliği \%90'dan fazladır. Bunlara ek olarak, Türkiye'de işsizler (\% 65.1) ve kendi işine (\% 88.2) sahip bireyler arasında hesap sahipliği diğerlerine (kamuda veya özel sektörde çalışanlar ve öğrenci veya emeklilere) göre düşüktür.

\subsubsection{Resmi Tasarruf Durumu ve Tasarruf Davranışları}

Finansal katılımının diğer bir ana göstergesi de; bir banka veya diğer bir finansal kurumda (mikrofinans kuruluşu veya diğer düzenlenmiş finansal kuruluşlarda) bir y1l içeresinde tasarruf etme ve para biriktirme işlemleridir (Fungáčová \& Weill, 2015; Özşuca, 2019) . Türkiye'de ankete katılmış bireylerin tasarruf davranışları ve resmi tasarruf düzeyi Tablo 3’te gösterilmektedir.

Türkiye'de ankete katılanların \% 78.54'ü son 12 ayda herhangi bir amaç için para biriktirmişlerdir. Katılımcıların para biriktirme amaçlarına göre, \% 15.8'i bir işi başlatmak veya geliştirmek için, \% 26.3'ü konut/taşıt alabilmek için, \% 42.1'i eğitim için (çoğunlukla 18-35 yaş arası katılanlar), \% 14.8'i yaşlılık dönemini düşünerek ve \% 55.6'sı diğer amaçlar için son 12 ayda tasarruf ettiklerini bildirmişlerdir. Katılımcıların \% 50.6'sı bir banka veya diğer resmi finansal kurum hesabını kullanarak, \% 11.2'si gayri resmi bir tasarruf grubunun nezdinde ve \% 34.9'u geleneksel metot olarak evde para biriktirmişlerdir.

Tablo 3. Tasarruf Davranışları ve Resmi Tasarruflar

\begin{tabular}{|c|c|}
\hline Tasarruf, Amacı ve Metodu & Yüzde \\
\hline Para biriktirenler (Son 12 ayda tasarruf edenler) & 78.54 \\
\hline \multicolumn{2}{|l|}{$\begin{array}{ll}\text { Tasarruf Amacı } \\
\end{array}$} \\
\hline Çiftçilik/işletme kurmak veya geliştirmek için & 15.8 \\
\hline Konut/taşıt alabilmek için & 26.3 \\
\hline Eğitim için & 42.1 \\
\hline Yaşl1lık dönemi için & 14.8 \\
\hline Diğer amaçlar için & 55.6 \\
\hline \multicolumn{2}{|l|}{ Tasarruf Etme Metodu } \\
\hline Banka veya diğer finansal kurum hesabında (resmi tasarruf) & 50.6 \\
\hline Aile dıșındaki bir kiși/gayri resmi bir tasarruf grubu nezdinde & 11.2 \\
\hline Kişisel olarak yastık altında & 34.9 \\
\hline
\end{tabular}




\subsubsection{Resmi Kredi Durumu ve Borçlanma Davranışları}

Finansal katılımının amaçlarından biri; bireylerin resmi finansmana erişimlerini arttırmaktır. Ankete katılan bireylerin yanıtlarına göre, Türkiye'de resmi finansman kaynağı olarak; bir banka veya diğer finansal kuruluştan borçlandığını beyan edenlerin yüzdesi, diğer borç kaynağı olarak; aileden borç alanların yüzdesinin altındadır. Ankete katılanların söz konusu resmi kredi ve borçlanma davranışları Tablo 4'te gösterilmektedir.

Anket verilere göre, Türkiye'de ankete katılanların \% 35,6's1 son 12 ayda herhangi bir amaç için borç aldığını beyan etmişlerdir. Ankete katılanların \% 7.9'u bir işi başlatmak veya geliştirmek için, \% 13.1'i eğitim için, \% 7.1'i sağlı için ve \% 26.2'si diğer amaçlar için son 12 ayda borç aldığını bildirmişlerdir. Katılanların, \% 20.4'ü resmi borç/kredi kaynağı olarak bir banka veya diğer resmi finansal kurumdan, \% 33.5'i aile, akraba veya arkadaşlardan ve \% 1.7'si gayri resmi bir tasarruf grubundan borç aldığını bildirmiştir. Yukarıdaki borçlanma amaçlara ilaveten, ankete katılanların \% 15.4'ünün 2020 yılında bir ev, daire veya arazi satın almak için kredileri de bulunmaktadır.

Tablo 4. Resmi Kredi ve Borç Alma Davranışları

\begin{tabular}{|l|c|}
\hline \multicolumn{1}{|c|}{ Borç/Kredi Alma Amacı } & Yüzde \\
\hline Borç alanlar & 35.6 \\
\hline Ev, daire/arazi satın almak için kredisi bulunmaktadır & 15.4 \\
\hline Çiftçilik/işletme kurmak veya geliştirmek için & 7.9 \\
\hline Eğitim için & 13.1 \\
\hline Sağlık için Alınmış Borç/Kredi Kaynakları & 7.1 \\
\hline Diğer amaçlar için & 26.2 \\
\hline \multicolumn{1}{|c|}{} & \\
\hline Banka/finansal kurumdan & 20.4 \\
\hline Aile, akraba/arkadaşlardan & 33.5 \\
\hline Gayri resmi bir tasarruf grubundan & 1.7 \\
\hline
\end{tabular}

\subsubsection{Banka/ATM Kartı, Kredi Kartı ve Sigorta Hizmetlerine Erişim}

Finansal katılımının ana göstergelerine (hesap sahipliği, remi tasarruf ve kredi) ek olarak diğer finansal ürünlerin kullanım derecesinin belirlenmesi de bir finansal sistemin kapsayıcılığını anlamak için gereklidir. Ankette sorulduğu gibi, bu ürünlerin bazıları; banka / ATM kartı, kredi kartı ve sigorta hizmetleridir.

Tablo 5'te görüleceği gibi, Türkiye'de bir bankada veya başka bir finansal kurumda hesabı olanların \% 98,8'i banka / ATM kartına sahip olup, \% 91,6'sı banka veya ATM kartını alışveriş yapmak için son 12 ayda kullanmıştır. Ankete katılanların \% 64.6'sı kredi kartına sahip olduğunu bildirmişler ve \% 60.4'ü son 12 ayda kredi kartını, ödeme yapmak için kullanmışlardır. Bu oran, kredi kartına sahip olanların tamamının, son 12 ayda kredi kartlarını ödeme işlemlerini yapmak için kullanmadığını göstermektedir. 
Tablo 5'te gösterildiği gibi, yukarıdaki bankacılık ürünlerinin kullanımına ilaveten; Türkiye'de ankete katılanların \% 69.8'i sigorta hizmetlerinden de yararlanmaktadırlar. Sigorta türüne göre; katılımcıların \% 52.5'inin sağlık sigortası ve \% 20.2'sinin hayat sigortası bulunmaktadır.

Tablo 5. Banka/ATM Kartı, Kredi Kartı ve Sigorta Hizmetlerinin Kullanımı

\begin{tabular}{|l|c|}
\hline \multicolumn{1}{|c|}{ Ürünler ve Kullanımı } & Yüzde \\
\hline Hesaba sahip olanların Banka/ATM kartı sahipliği & 98.8 \\
\hline Son 12 ayda banka/ATM kartını alışveriş yapmak için kullanılmış & 91.6 \\
\hline Kredi kartı sahipliği & 64.6 \\
\hline Son 12 ayda kredi kartını kullanılmış & 60.4 \\
\hline Sigorta hizmetlerden yararlanır & 69.8 \\
\hline Hayat sigortası bulunmaktadır & 20.2 \\
\hline Sağlık sigortası bulunmaktadır & 52.5 \\
\hline Araç sigortası bulunmaktadır & 34.2 \\
\hline Tarım, hayvancılık vb. sigortası bulunmaktadır & 2.3 \\
\hline
\end{tabular}

\subsection{5. İnternet Bankacılığı ve Mobil Bankacılık}

Cep telefonu ve internet, bir hesaptan doğrudan ödeme yapmak için banka ve kredi kartlarına göre daha fazla alternatif sunmaktadır. Bireyler cep telefonu ve interneti kullanarak hesap bakiyesini kontrol edebilir, faturalarını ödeyebilir, havale işlemlerini gerçekleştirebilir, ayrıca dünyanın her yerinden çevrimiçi olarak bir şey satın alabilir. Dünya genelinde, her gün gittikçe artan teknoloji ve finansal alanlardaki yenilikler ile beraber benzer hizmetler de çoğalmaktadır. Ama bu hizmetlerden yararlanma düzeyi, ülkeler arasında farklık gösterir. Örneğin; 2017 yılında, gelişmiş ülkelerde mobil ve internet bankacılığından yararlanan bireylerin oran $\%$ 50'den fazla olup gelişmekte olan ülkelerde \% 20'ye yakın (DemirgucKunt vd., 2018: 7) ve gelişmemiş ülkelerde çok düşük olduğu görülmektedir.

Anket verilerine bakıldığında, söz konusu hizmetlerden yaralanma derecesinin iyi bir düzeyde olduğu ifade edilebilir. Söz konusu hizmetlerin kullanımına ilişkin anket verileri Şekil 2'de gösterilmektedir.

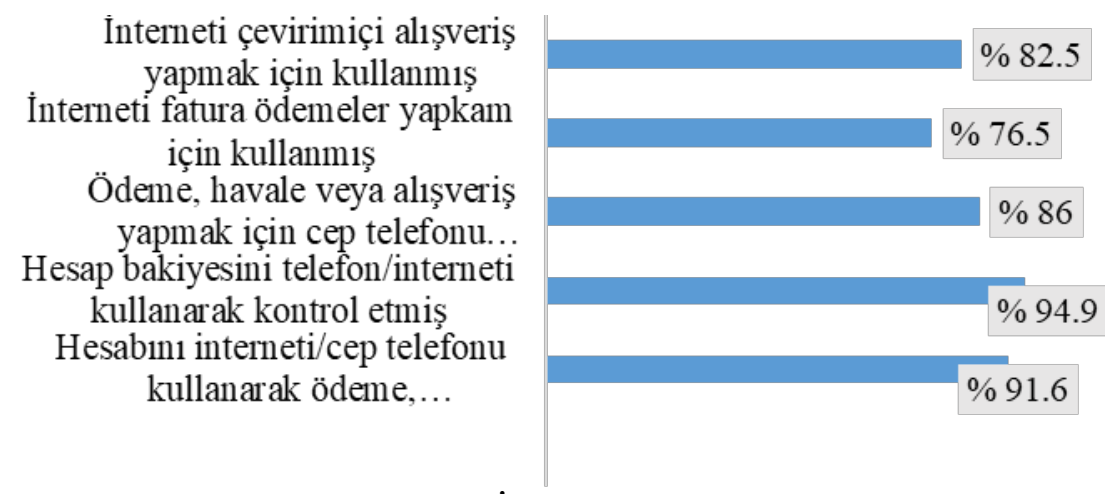

Şekil 2. İnternet ve Mobil Bankacılığg 
Ankete katılan ve banka hesap sahibi olan bireylerin \%91.6's1, son 12 ayda cep telefonu veya internet vasıtasıyla, kendi hesabını ödeme işlemlerini yapmak, havale işlemlerini gerçekleştirmek veya alışveriş için kullanmışlardır. Buna ek olarak, Türkiye'de, ankete katılan ve banka hesabı olanların \% 94.9'u cep telefonu veya interneti kullanarak hesap bakiyesini kontrol etmişlerdir. Ayrıca bu ülkede, banka hesap sahipliğine bakılmadan ankete katılan bireylerin \% 82.5'i interneti çevrimiçi alışveriş yapmak ve \% 76.5'i fatura ödemeleri yapmak için kullanmaktadır. Ayrıca hesap sahipliğine bakılmaksızın, ankete katılanların \% 86's1 cep telefonu; mobil bankacilık hizmetleri olarak ödeme, havale ve alışveriş yapmak için de kullanmışlardır (bu, dolaylı erişim olarak, diğer kişilerin hesabının kullanımı da içerebilir). Anket verilere göre, Türkiye'de son 12 ayda çevrimiçi alışveriş̧ yapmış bireylerin \% 89.1'i satın aldığı ürünlerin ödemelerini online bir şekilde yapıp geriye kalan \% 10.9'unu kapıda nakit ödeme şeklinde yapmalarını bildirmiş̧lerdir.

\subsection{Banka Dışında Kalan Kitle (Unbanked Population) ve Finansal Dışlanma Nedenleri}

Banka dışı kalan kitle ya da finansal olarak dışlanmış kitle; banka veya diğer finansal kurumlarda hesabı bulunmayan bireyler olarak ifade edilir (Demirguc-Kunt vd., 2018: 35). Genel olarak, bir ekonomide bireylerin iki nedenden dolayı finansal hizmetlere erişimi sağlanamamaktadır. Bunlar; isteğe bağlı nedenler ve piyasa yetersizliğinden veya kusurundan kaynaklanan nedenlerdir (World Bank, 2014: 16) . Türkiye'de banka dı̧̧ kalan kitle "Hesap Sahipliği”' başlığı altında Şekil 1'de gösterildiği gibi; katılan bireylerin sadece \% 10.2'sine tekabül etmektedir.

Bir ekonomide finansal dışlanma düzeyini düşürmek ve banka dışı kitleyi azaltmak için, bireyler arasında finansal hizmetlere erişim ve bu hizmetlerin kullanımını, özellikle hesap sahipliğini arttırmak için banka veya diğer finansal hesap sahipliğinin önündeki engellerin (finansa dişlanma nedenleri) belirlenmesi gerekir. Ankete katılanlar tarafindan bildirilmiş engeller Şekil 3’te gösterilmiştir.
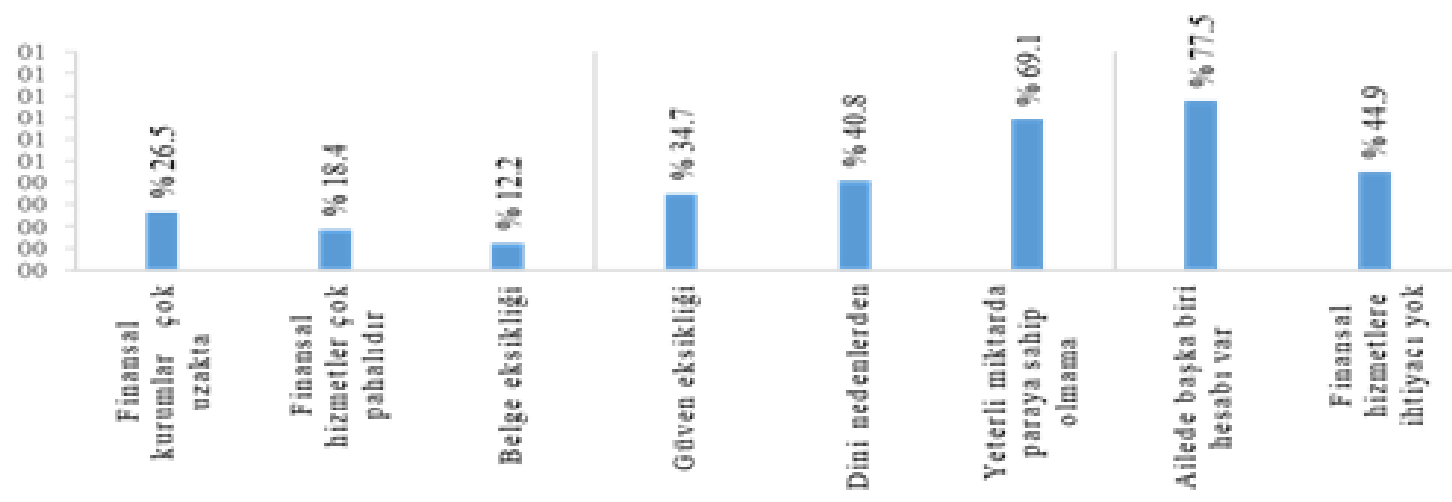

Şekil 3. Banka veya Diğer Finansal Kurumlarda Hesap Sahipliğinin Önündeki Engeller

Görüleceği gibi; Türkiye'de hesap sahipliğinin (finansal katılım ilk ve temel göstergesi) önündeki engeller, hem isteğe bağl 1 nedenlerden hem de finansal piyasa kusurundan ve yetersizliğinden kaynaklanmaktadır. Şekil 3'e göre, banka dışı kitle olan 
bireylerin çoğu isteğe bağlı nedenlerden; özellikle ailede birinin hesabının var olmasından dolayı bir banka veya diğer bir finansal kurumda hesap açtırmamıştır.

Ankete katılan ve hesabı olmayan bireylerin \% 77.5'i ailede başka birinin hesabının var olduğunu, \% 69.1'i yeterli miktarda paraya sahip olmadığını, \% 44.9'u finansal hizmetlere ihtiyacının olmadığını ve \% 40.8'i dini nedenleri (isteğe bağlı nedenler) banka hesabı olmaması nedeni olarak beyan etmişlerdir. Ayrıca, söz konusu bireylerin \% 26.5'i finansal kurumların çok uzakta olduğunu, \% 18.4'ü finansal hizmetlerin çok pahalı olduğunu, \% 12.2'si belge eksikliğini ve \% 34.7'sinin finansal kurumlara güven duymamasını banka hesap sahipliğinin önündeki engeller olarak bildirilmiştir.

\subsection{Probit Regresyon Analizinin Bulguları ve Finansal İçerme Ana Göstergelerinin Belirleyicileri}

Probit regresyon analizinde, doğrusal regresyon analizinden farklı olarak, bağımlı değişken kukla değişken olmalıdır (ikili). Bağımlı ve bağımsız değişkenler arasında doğrusal ilişkinin var olması gerekmez, bağımlı değişkenin ve hata terimlerinin normal dağılması gerekli değildir. Bağımsız değişkenler ise birbirleriyle ilişkili (çoklu bağıntı) olmamalıdır (Alp, 2007: 3, 23; Schreiber-Gregory, 2018: 4). Ayrica, Probit regresyonunda, katsay1 değerleri, bağımsız değişkenlerin bağımlı değişkenler üzerindeki etkisini tahmin etme olasılıklarını göstermez, bu nedenle bağımsız değişkenlerin bağımlı değişkenler üzerindeki olası etkilerini tahmin etmek için Probit regresyonunun marjinal etkisine bakılır.

Literatürde bireysel özellik olarak; cinsiyet, yaş, gelir ve eğitim düzeyi finansal katılımı etkileyen faktörler olarak kabul edilmektedir (Fungáčová ve Weill, 2015: 196; Karakus, 2020: 147; Nandru vd., 2016: 141; Özşuca, 2019: 1377; Tuesta vd., 2015: 2). Araştırmanın bu bölümünde, anket yöntemiyle elde edilmiş birincil verileri kullanarak finansal katılım göstergelerini etkileyen faktörlerin belirlenmesine odaklanılmıştır.

Analizde bir finansal kurumda hesap sahibi olma, tasarruf etme (resmi tasarruf), bu kurumlardan borç veya kredi alma (resmi kredi), kredi kartı sahipliği ve sigorta hizmetlerden yararlanma durumu bağımlı değişkenler olarak alınmıştır; bireysel özellikler; cinsiyet, yaş, gelir ve eğitim düzeyi ise bağımsız değişkenler olarak kullanılmaktadır. Bağımlı ve bağımsız değişkenlerin tanımlayıcı istatistikleri Tablo 6'da gösterilmiştir. Analizde bağımlı değişkenler, ikili veya kukla değişkenler olarak kullanılırken sadece 1 ve 0 değeri alır. Yani; a) bir birey bir resmi finansal kurumda hesaba sahip ise, b) bir resmi finansal kurumda son 12 ayda tasarruf etmiş ise, c) bir resmi finansal kurumdan son 12 ayda kredi almış ise d) kredi kartına sahip ise ve e) sigorta hizmetlerinden yararlanıyorsa bir (1) değerini alır. Aksi takdirde sıfır (0) değerini alır.

Bağımsız değişkenlerde; a) kadın değişkeni; cinsiyet kadın ise bir, erkekse 0 değeri ile ifade edilip; b) yaş ve yaşın karesi² (yaş² ) sürekli değişkenler olarak kullanılmıştır. Gelir kategorileri için dört kukla değişken bulunmaktadır. Eğer bir kişinin geliri belirli bir kategorideyse bir (1) değerini alır, yoksa sıfır (0) değerini alır. Her iki ülkede birinci gelir kategorisi ${ }^{3}$ karşılaştırmak için temel kategori olarak kullanılmıştır. Eğitim düzeyi için de iki

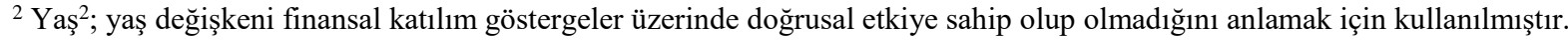

${ }^{3}$ Birinci gelir kategorisi esas kategori regresyon analizinden çıkarılmıştır.
} 
kukla değişken bulunmaktadır. Eğer bir bireyin eğitimi belirli bir seviyede ise bir değerini alır, aksi takdirde sıfır kullanılmıştır. Eğtim değişkeni ile ilgili olarak, ilköğretim veya altı (çıkarılmış eğitim düzeyi) karşılaştırma için temel kategori olarak kullanılmıştır.

Tablo 6. Ampirik Analizde Değişkenlerin Tanımlayıcı İstatistikleri

\begin{tabular}{lccccc}
\hline Değişken & N & Ortalama & Standart Sapma & Asgari & Azami \\
\hline Hesap Sahipliği & 480 & 0.898 & 0.303 & 0 & 1 \\
Resmi Tasarruf & 480 & 0.506 & 0.500 & 0 & 1 \\
Resmi Kredi & 480 & 0.204 & 0.404 & 0 & 1 \\
Kredi Kartı & 480 & 0.646 & 0.479 & 0 & 1 \\
Sigorta & 480 & 0.698 & 0.46 & 0 & 1 \\
Kadın & 480 & 0.435 & 0.496 & 0 & 1 \\
Yaş & 480 & 32.646 & 10.994 & 18 & 64 \\
Yaş & 480 & 1186.37 & 830.77 & 324 & 4096 \\
2. Gelir Kategori & 480 & 0.369 & 0.483 & 0 & 1 \\
3. Gelir Kategori & 480 & 0.217 & 0.412 & 0 & 1 \\
4. Gelir Kategori & 480 & 0.052 & 0.222 & 0 & 1 \\
5. Gelir Kategori & 480 & 0.025 & 0.156 & 0 & 1 \\
Ortaöğretim / lise & 480 & 0.131 & 0.338 & 0 & 1 \\
Yükseköğretim veya Daha Fazlası & 480 & 0.825 & 0.380 & 0 & 1 \\
\hline
\end{tabular}

Probit regresyon analizinin marjinal etkilerinin sonuçları Tablo 7'de sunulmaktadır. Tabloda yer alan sütunlar, bağımlı değişkenleri; hesap sahipliği, resmi tasarruf, resmi kredi kullanımı, kredi kartı sahipliği ve sigortayı ayrı ayrı modeller olarak göstermektedir. Satırlarda bağımsız değiş̧enler (bireysel özellikleri) verilmiştir. Genel olarak, tablolarda parantez içinde yer alan değerler, sağlam standart hataları (robust standard errors) ve parantez dışında yer alan değerler probit regresyonun marjinal etkisini; yani bir kişinin bireysel özelliklerinin finansal katılım göstergelerini nasıl etkilediğini ifade etmektedir. Marjinal değerler üzerinde gösterilmiş yıldız simgeleri; her bir marjinal değerin istatistiksel anlamlılık düzeyini; yani $\left({ }^{* *}\right) \mathrm{p}<\% 1$, $\left({ }^{* *}\right) \mathrm{p}<\% 5$ ve $\left({ }^{*}\right) \mathrm{p}<\% 10$ ifade eder. Tablonun son kısmında yer alan 'Pseudo $\mathrm{R}^{2}$; 0 ve 1 arasında değer alıp modellerin uyumunu gösterir. Pseudo $\mathrm{R}^{2}$ değerindeki artış, modelin uyum iliğini arttırır. Log likelihood, Ki-Kare olabilirlik oranı testinde, modeldeki tüm katsayıların aynı anda sıfır olup olmadığını test etmek için kullanılır. Log likelihood sıfır ve negatif sonsuz arasında değer alıp, bu değer ne kadar sıfira yakınsa o kadar iyidir. Prob > chi $^{2} ; \% 1$ veya $\% 5$ anlamlılık düzeyinde, tüm katsayıların sıfira eşit olmadığını gösterip modellerin bir bütün olarak istatistiksel anlamlılığını ifade eder.

Tablo 7'de gösterildiği gibi, ilk açıklayıcı değişken olarak, kadın olma ile hesap sahipliği, resmi tasarruf ve resmi kredi kullanımı arasında anlamlı bir ilişkisi bulunamamıştır. $\mathrm{Bu}$ durum, Türkiye'de değinilmiş 3 finansal hizmetin kullanımında, erkekler ve kadınlar arasında istatistiksel olarak anlamlı bir farklılık olmadığına işaret eder. Bireylerin yaşı ve FK ilişkisinin test edildiği analiz sonuçlarına göre, bir bireyin yaşı sadece hesap sahipliğini anlamlı ve pozitif bir şekilde etkilemiştir. Bu, büyük yaştaki bir bireyin Türkiye'de hesap sahibi olma olasılığının küçük yaşta olan bir bireye göre daha yüksek olduğu anlamına gelir.

Not: Tablolarda yer alan; 2. gelir kategorisi $=2.000-5.000 \mathrm{TL}, 3$. gelir kategorisi $=5001-10.000,4$. gelir kategorisi ise $=$ 10.001-20.000 TL ve 5. gelir kategorisi = 20.001 TL ve üzeri kategorileri ifade eder. 
Araştırmada, yaşın hesap sahipliği üzerinde doğrusal bir etkiye sahip olup olmadığını anlamak için, yaş ${ }^{2}$ değişkeni kullanılmıştır. Probit regresyon analizinin sonucuna göre, yaş ${ }^{2}$ değişkeninin hesap sahipliği ile negatif ve anlamlı etkisi bulunmuştur. Yani, bir bireyin yaşının bir banka veya diğer finansal kurumda hesap sahibi olma olasılığı üzerinde anlamlı bir etkisinin olduğunu ancak bu ilişkinin doğrusal olmadığını gösterir.

Finansal katılımının bir başka etkileyici faktörü olan gelir düzeyi, resmi bir finansal kurumda hesap sahipliği, resmi tasarruf ve resmi kredi üzerinde istatistiksel olarak anlamlı bir etkiye sahiptir. Tablo 7'de gösterildiği gibi, Türkiye'de 4. ve 5. gelir kategorilerde yer alan bir birey, 1. gelir kategorisinde yer alan bir kişiye göre (çıkarılmış 1 . gelir kategorisi $=2000 \mathrm{TL}$ altında) resmi bir finansal kurumda hesaba sahip olma olasılı̆̆ $\% 7.3$ daha yüksektir. Ayrıca, gelir ve resmi tasarruf ilişkisini incelendiğinde, 3 . ve 5. gelir kategorilerde yer alan bireyler 1 . gelir kategorideki bir bireye göre, resmi bir finansal kurumda tasarruf etme olasılı̆̆ sırasıyla \% 23.6 ve \% 61.4 daha yüksektir. Bu durum, bireylerin gelir düzeyinin resmi tasarruflar üzerindeki pozitif etkisini ifade eder. Yani bireylerin geliri arttıkça bir finansal kurumda tasarruf etme olasılıkları da artar. Buna ek olarak, gelir düzeyinin resmi kredi ile ilişkisine bakıldığında, 2., 3. ve 5. gelir kategorilerinde yer alan bireylerin 1. gelir kategorisindeki bireylere göre resmi bir finansal kurumdan kredi veya borç alma olasılığı sırasıyla \% 10.3, \% 13.4 ve \% 38.4 daha yüksektir. Bu da gelir düzeyinin Türkiye'de bir banka veya diğer finansal kurumdan borç alma olasılığı ile pozitif ilişkisini gösterir.

Türkiye'de bireylerin eğitim düzeyi ve ana finansal katılım göstergeleri ile ilişkisine bakıldığında, Tablo 7'de gösterildiği gibi, sadece hesap sahipliği ve resmi tasarruf ile istatistiksel olarak anlamlı ilişkili olup, resmi kredi ile anlamlı ilişkisi bulunmamıştır. Yükseköğrenim düzeyinde öğrenim görmüş bir bireyin, bir banka veya diğer bir resmi finansal kurumda hesaba sahip olma ihtimali, ilköğretim veya alt eğitim düzeyine sahip bir bireye göre \% 36.9 daha yüksektir. Ayrıca, bireylerin eğitim düzeyi bir banka veya diğer resmi bir finansal kurumda tasarruf etme üzerinde de anlamlı bir etkiye sahiptir. Ortaöğretim veya lise düzeyinde eğitim görmüş bir kişinin resmi bir finansal kurumda tasarruf etme ihtimali ilköğretim veya alt düzeyinde eğitim görmüş bir bireye göre $\% 43.1$ daha yüksektir. $\mathrm{Bu}$ olasılık, yükseköğrenim ve üzeri düzeyde öğrenim görmüş bir birey için \% 49.6'dır. Kısaca, Türkiye'de bir bireyin yüksek eğitim düzeyi bir resmi finansal kurumda hesaba sahip olmasının ve tasarruf etmesinin olasılığını arttırır.

Kişilerin bireysel özellikleri, FK ana göstergeleri üzerindeki etkisine ek olarak, kredi kart sahipliği ve sigorta hizmetlerinden yararlanmayı da etkilemektedir. Tablo 7'de gösterildiği gibi; cinsiyet ve yaş, kredi kart sahipliği ve sigorta hizmetlerinin kullanımı ile istatistiksel olarak anlamlı bir ilişkiye sahip değildir. Ancak, bireylerin gelir düzeyinin, hem kredi kartı sahipliği ile hem de sigorta hizmetlerinin kullanımı ile istatistiksel olarak anlamlı ve pozitif ilişkisi bulunmuştur. Diğer bir ifade ile, 2., 3., veya 5. gelir kategorilerde yer alan bireylerin kredi kartına sahip olma olasılığ 1 1. gelir kategorisinde yer alan bir bireye göre sirasıyla \% 16.7, \% 35.6 ve \% 38.3 daha yüksektir. Sigorta hizmetlerin kullanım ve gelir ilişkisine bakıldığında, 2., 3. veya 4 gelir kategorilerde yer alan bireylerin 1. kategoride yer alan bir bireye göre, sigorta hizmetlerden yararlanma olasılığı sırasıyla \% 20.3, \% 32.9 ve \% 41.1 daha yüksektir. 
Tablo 7. Finansal Katılım Belirleyicileri İçin Probit Regresyon Olasılık Değerleri ve

Marjinal Etki Değerleri

\begin{tabular}{|c|c|c|c|c|c|}
\hline \multirow{3}{*}{ Değişkenler } & \multicolumn{5}{|c|}{ Türkiye } \\
\hline & (1) & (2) & (3) & (4) & (5) \\
\hline & $\begin{array}{c}\text { Hesap } \\
\text { Sahipliği }\end{array}$ & $\begin{array}{c}\text { Resmi } \\
\text { Tasarruf }\end{array}$ & $\begin{array}{l}\text { Resmi } \\
\text { Kredi }\end{array}$ & $\begin{array}{l}\text { Kredi } \\
\text { Kartı }\end{array}$ & Sigorta \\
\hline Kadın & $\begin{array}{l}-0.025 \\
(0.0170)\end{array}$ & $\begin{array}{c}0.007 \\
(0.0493)\end{array}$ & $\begin{array}{l}-0.028 \\
(0.0376)\end{array}$ & $\begin{array}{c}0.001 \\
(0.0478)\end{array}$ & $\begin{array}{l}-0.028 \\
(0.0425)\end{array}$ \\
\hline Yas & $\begin{array}{l}0.012 * * \\
(0.0052)\end{array}$ & $\begin{array}{l}-0.029 * \\
(0.0174)\end{array}$ & $\begin{array}{c}0.023^{*} \\
(0.0132)\end{array}$ & $\begin{array}{c}0.023 \\
(0.0158)\end{array}$ & $\begin{array}{c}-0.007 \\
(0.0143)\end{array}$ \\
\hline Yas $^{2}$ & $\begin{array}{c}0.000 * * * \\
(0.0001)\end{array}$ & $\begin{array}{c}0.000 * \\
(0.0002)\end{array}$ & $\begin{array}{l}-0.000 * \\
(0.0002)\end{array}$ & $\begin{array}{l}-0.000 \\
(0.0002)\end{array}$ & $\begin{array}{c}0.000 \\
(0.0002)\end{array}$ \\
\hline 2. Gelir Kategori & $\begin{array}{c}0.012 \\
(0.0320)\end{array}$ & $\begin{array}{c}0.093 \\
(0.0624)\end{array}$ & $\begin{array}{l}0.103^{* *} \\
(0.0415)\end{array}$ & $\begin{array}{c}0.167 * * * \\
(0.0621)\end{array}$ & $\begin{array}{c}0.203 * * * \\
(0.0605)\end{array}$ \\
\hline 3. Gelir Kategori & $\begin{array}{c}-0.048 \\
(0.0550)\end{array}$ & $\begin{array}{c}0.236 * * * \\
(0.0788)\end{array}$ & $\begin{array}{l}0.134^{* *} \\
(0.0576)\end{array}$ & $\begin{array}{c}0.356 * * * \\
(0.0679)\end{array}$ & $\begin{array}{c}0.329 * * * \\
(0.0681)\end{array}$ \\
\hline 4. Gelir Kategori & $\begin{array}{c}0.073 * * * \\
(0.0266)\end{array}$ & $\begin{array}{c}0.200 * \\
(0.1211)\end{array}$ & $\begin{array}{c}0.120 \\
(0.0977)\end{array}$ & $\begin{array}{l}0.170 \\
(0.1209)\end{array}$ & $\begin{array}{c}0.411 * * * \\
(0.0779)\end{array}$ \\
\hline 5. Gelir Kategori & $\begin{array}{c}0.073 * * * \\
(0.0266)\end{array}$ & $\begin{array}{c}0.614 * * * \\
(0.0463)\end{array}$ & $\begin{array}{l}0.384 * * \\
(0.1504)\end{array}$ & $\begin{array}{c}0.383 * * * \\
(0.1192)\end{array}$ & $\begin{array}{c}0.483 \\
(0.0481)\end{array}$ \\
\hline Ortaöğretim / lise & $\begin{array}{c}0.227 * \\
(0.1235)\end{array}$ & $\begin{array}{c}0.431 * * * \\
(0.0945)\end{array}$ & $\begin{array}{c}0.145^{*} \\
(0.0867)\end{array}$ & $\begin{array}{c}0.185 \\
(0.1293)\end{array}$ & $\begin{array}{c}0.109 \\
(0.1256)\end{array}$ \\
\hline $\begin{array}{l}\text { Yükseköğretim veya } \\
\text { Daha Fazlası }\end{array}$ & $\begin{array}{r}0.369 * * * \\
(0.1185)\end{array}$ & $\begin{array}{r}0.496 * * * \\
(0.0755)\end{array}$ & $\begin{array}{c}0.119 \\
(0.0725)\end{array}$ & $\begin{array}{c}0.432 * * * \\
(0.1182)\end{array}$ & $\begin{array}{c}0.066 \\
(0.1205)\end{array}$ \\
\hline Gözlemler & 480 & 480 & 480 & 480 & 480 \\
\hline Pseudo R2 & 0.239 & 0.0764 & 0.0564 & 0.148 & 0.085 \\
\hline Log pseudo likelihood & -120.453 & -307.250 & -229.243 & -265.969 & -269.174 \\
\hline Prob $>$ chi2 & 0.0000 & 0.0000 & 0.0017 & 0.0000 & 0.0000 \\
\hline
\end{tabular}

Bireylerin eğitim düzeyine bakıldığında, yükseköğrenim veya üst eğitim düzeyine sahip olan bir bireyin, ilköğretim veya alt eğitim düzeyine sahip olan bir bireye göre, kredi kartına sahip olma olasılığı \% 43.2 daha yüksektir. Ancak, eğitim düzeyi ve sigorta hizmetlerinin kullanımı ile istatiksel olarak anlamlı bir ilişki bulunmamıştır.

Probit modelin bir varsayımı olarak; bağımsız değişkenlar arasında çoklu bağıntı olmadığını test etmek için varyans büyütme faktörü (variance inflation factor) testi kullanılmıştır. Tablo 8'e göre, bağımsız değişkenlere ait varyans büyütme faktörü (VIF), 10 değerinden küçük olduğu için, çoklu bağıntı olmadığı sonucuna ulaşılmış ${ }^{4}$

\footnotetext{
${ }^{4}$ Regresyonda kullanılan Yaş2' değişkeni, bireylerin yaşı finansal katılım göstergeler üzerinde doğrusal etkiye sahip olup olmadığını belirlemek için kontrol değişkeni olarak kullanılmıştır. Kontrol değişkenden dolayı Yaş ve Yaş2 arasında bağıntı var olduğu önemli görülmemiştir.
} 
Tablo 8. Regresyonda Kullanılan Bağımsız değişkenlerin VIF Test Sonucu

\begin{tabular}{|l|c|c|}
\hline & \multicolumn{2}{|c|}{ Türkiye } \\
\hline Değişken & VIF & 1/VIF \\
\hline Kadın & 1.08 & 0.928 \\
\hline Yas & 1.52 & 0.660 \\
\hline 2. Gelir Kategori & 1.50 & 0.668 \\
\hline 3. Gelir Kategori & 1.72 & 0.582 \\
\hline 4. Gelir Kategori & 1.32 & 0.758 \\
\hline 5. Gelir Kategori & 1.15 & 0.869 \\
\hline Ortaöğretim / lise & 3.92 & 0.255 \\
\hline Yükseköğretim veya Daha Fazlası & 4.32 & 0.231 \\
\hline VIF Ortalama & 2.07 & \\
\hline
\end{tabular}

\section{TARTIŞMA VE SONUÇ}

Finansal katılım ekonomik değişkenler (yoksulluk, işsizlik, ekonomik büyüme vb.) ve finansal istikrar üzerindeki etkisi açısından son yıllarda önem kazanmakta, politikaların ve araştırmaların odaklandığı konulardan olmaktadır. Bir ülkedeki finansal katılım düzeyinin ve belirleyicilerin tespit edilmesi, finansal katılımı etkileyen politikaları ele almak için büyük öneme sahiptir.

$\mathrm{Bu}$ araştırmanın sonucu olarak; Türkiye'de 2020 yılında finansal katılımının ilk ve temel göstergesi olan hesap sahipliği oranı $\% 89.8^{\prime}$ dir. Geriye kalan kısım, yani ankete katılanların \% 10.2'si banka dışı kalan kitle olarak adlandırılmaktadır. Finansal olarak dışlanmış bireylerde en çok gönüllü dışlanmanın -özellikle finansal hizmetlere dolaylı erişim sebebiyle (ailede başka birinin hesaba sahip olması)- olduğu tespit edilmiştir. Bireysel özelliklere göre; kadınlar ve erkekler arasında hesap sahipliği oranında önemli bir fark yoktur; eğitim düzeyine göre ise büyük farklılık bulunmaktadır. İlköğretim veya altı düzeyinde eğitim görmüş bireyler ile yükseköğrenim görmüş bireyler arasında yüzde 52'lik bir fark vardır. Gelir açısından sadece 2.000 TL altında gelire sahip olan bireyler arasında hesap sahipliği, diğer yüksek gelir düzeyindeki bireylere göre düşüktür. Bireylerin çalş̧ma durumuna göre, işsiz olan bireyler en çok banka dışı kalan kitle olarak görülür. Bireylerin yaş gruplarına göre en çok 50 yaştan büyük olan bireylerin, diğer yaştakilere göre bir banka veya diğer bir finansal kurumda hesap sahipliği oranı düşüktür. Hesabı olan bireylerin yüzde 90'dan fazlası, son 12 ayda hesaplarını farklı finansal işlemleri gerçekleştirmek için kullanmışlar. Bir banka veya diğer bir finansal kurum hesabını kullanarak tasarruf etme yöntemi, diğer tasarruf etme yöntemlerine göre (evde/gayri resmi tasarruf grubu nezdinde) daha yaygındır. Bu durum, finansal katılım açısından önemlidir ve var olan hesapların aktif bir şekilde kullanımını gösterir. Ancak, borç kaynağı olarak; aile, akraba ve arkadaşlardan borç alma yöntemi, resmi finansal kurumlardan borç veya kredi alma yöntemine göre daha yaygındır.

Finansal katılımının ana göstergelerine ek olarak, kredi kartı sahipliği ve sigorta hizmetlerinden yararlanma oranı, yüzde altmış ve yetmiş arasındadır. Ayrıca, bireylerin çoğu mobil bankacılık ve internet yoluyla hesaplarını farklı işlemleri gerçekleştirmek için kullanmaktadır. 
Yapılan Probit regresyon sonucu olarak; cinsiyet değişkeninin FK göstergelerini istatistiksel olarak anlamlı bir etkisi bulunmamaktadır. Bu durum, Türkiye'de erkekler ve kadınlar arasında hesap sahipliği açısından anlamlı farklılık olmadığını ifade eder. Bu sonuç, Tuesta vd. (2015) ampirik analiz sonuçları ile uyumlu olup, Özşuca (2019) ve Karakus (2020) analiz sonuçlarından farklıdır. Karakuş (2020) ve Özşucanın yaptığı (2019) ampirik analiz sonuçlarına bakıldığında, bireysel özellik olarak; cinsiyetin finansal katılım temel göstergesi olan hesap sahipliği üzerindeki etkisi 2011'den 2017'ye kadar sürekli azalmaktadır. Bireylerin cinsiyet ile finansal katılım ilişkisine ait bu araştırmanın bulguları, Türkiye'de finansal katılımının kapsamını genişletmeyi amaçlayan stratejilerin etkili olduğuna işaret etmektedir.

Bireylerin gelir düzeyi, FK göstergeleri ile pozitif ilişkilidir. Diğer bir ifade ile bireylerin geliri arttıç̧a hesap sahipliği, resmi tasarruf etme, resmi kredi alma, kredi kart sahipliği ve sigorta hizmetlerden yararlanma olasılığı da artar. Ayrıca bireylerin eğitim düzeyi de hesap ve kredi kartına sahip olma ve resmi tasarruf etme olasılığını pozitif bir şekilde etkilemiştir. Ancak eğitim düzeyi resmi kredi ve sigorta hizmetlerden yararlanma ile istatistiksel olarak anlamlı ilişkili değildir. Gelir ve eğitim düzeyinin, hesap sahipliği ve resmi tasarruf (gelir düzeyi resmi krediyi de) ile anlamlı ilişkili olduğu sonucu, Çin'de Fungáčová ve Weill (2015); Argentina'da Tuesta vd. (2015); Türkiye'de Ö̈zşuca (2019) ve Karakuş'un (2020) analiz sonuçlarını desteklemektedir.

Ayrıca, bireylerin yaşı, sadece hesap sahipliği ile anlamlı ilişkiye sahip olup, diğer göstergeler ile önemli ölçüde ilişkili değildir. Bu bulgu genel olarak, yaşın hesap sahipliği ile ilişkisi açısından taranmış literatür ile uyumlu olup, diğer göstergeler ile anlamlı ilişkisi bulunmaması açısıdan farklılık arz etmektedir.

Özet olarak; finansal katılımının tüm göstergeleri açısından bakıldığında finansal katılım iyi ve yüksek düzeydedir. Bireylerin eğitim düzeyi finansal katılımının en etkili belirleyicilerindendir. Buna ilaveten, bireylerin gelir düzeyi finansal katılım düzeyini çok etkileyen diğer bir etkendir.

\section{KAYNAKLAR}

Al-Smadi, Mohammad O (2018), “The Role of Financial Inclusion in Financial Stability: Lesson From Jordan”, Banks and Bank Systems, 13(4), pp. 31-39.

Alp, Aykut (2007), İstatistiksel Çalışmalarda Probit Analizi ve Uygulama Alanları, (Yüksek Lisans Tezi), Dicle Üniversitesi, Türkiye.

Başbakanlık Hazine Müsteşarlığı (2014), Hazine Müsteşarlığı Stratejik Planı 2014 - 2018, Başbakanlık Hazine Müsteşarlığı, Ankara.

Başbakanlık (2014), Finansal Erişim, Finansal Eğitim, Finansal Tüketicinin Korunması Stratejisi ve Eylem Planları, 10/2014 Sayılı Başbakanlık Genelgesi, 5.7.2014 Tarihli ve 29021 Sayıl1 Resmi Gazete. 
BDDK (2019), 2019-2021 Dördüncü Stratejik Plan, Bankacılık Düzenleme ve Denetleme Kurumu, İstanbul.

Chibba, Michael (2009), "Financial Inclusion, Poverty Reduction and The Millennium Development Goals”, The European Journal of Development Research, 21(2), pp. 213-230.

Demirguc Kunt, Asli - Klapper, Leora (2012), Measuring Financial Inclusion: The Global Findex Database, The World Bank, Washington, D.C., United States.

Demirguc Kunt, Asli - Klapper, Leora - Singer, Dorothe - Ansar, Saniya - Hess, Jake (2018), The Global Findex Database 2017: Measuring Financial Inclusion and The Fintech Revolution, The World Bank, Washington, D.C., United States.

Demirguc-Kunt, Asli - Klapper, Leora - Singer, Dorothe - Van Oudheusden, Peter (2015), The Global Findex Database 2014: Measuring Financial Inclusion Around The World, The World Bank, Washington, D.C., United States.

Fungáčová, Zuzana - Weill, Laurent (2015), “Understanding Financial Inclusion in China”, China Economic Review, 34, pp. 196-206.

Gebeşoğlu, Fulya Özorhan (2015), “Türkiye'de Finansal Kapsama Seviyesi Üzerine Bir Değerlendirme”, Bankacılar Dergisi, 26(95), ss. 69-84.

Hannig, Alfred - Jansen, Stefan (2010), Financial Inclusion and Financial Stability: Current Policy Issues, SSRN, ADBI Working Paper 259. Tokyo: Asian Development Bank Institute.

Iqbal, Badar Alam - Sami, Shaista (2017), “Role Of Banks in Financial Inclusion in India”, Contaduríay Administración, 62(2), pp. 644-656.

Karakus, Rifat (2020), “Türkiye'de Finansal Tabana Yayılma Düzeyi ve Belirleyicileri”, Business and Economics Research Journal, 11(1), ss. 147-160.

Korkmaz, Şule (2016), Finansal İçerme : Türkiye'de Finansal Erişim Üzerine Bir Model Uygulamas1, (Doktora Tezi), İstanbul Üniversitesi, İstanbul (55719).

Nandru, Prabhakar - Byram, Anand - Rentala, Satyanarayana (2016), '’Determinants of Financial Inclusion: Evidence from Account Ownership and Use of Banking Services", International Journal of Entrepreneurship and Development Studies, 4(2), pp. 141-155.

Nasr, Anthony Tanios (2017), The Interplay of Credit, Savings, and Vulnerability: A Study of Financial Inclusion in Kenya, Cornell University, Ithaca, New York.

Özşuca Ekin, Ayşe (2019), "Financial Inclusion in Turkey: Evıdence From Individual Level Data”, Ankara Üniversitesi SBF Dergisi, 74(No. 4), pp. 1377 - 1400. 
Sarma, Mandira - Pais, Jesim (2011), “Financial Inclusion and Development”, Journal of International Development, 23(5), pp. 613-628.

Schreiber-Gregory, Dn (2018), Logistic and Linear Regression Assumptions: Violation Recognition and Control, Henry M Jackson Foundation, Papre 130.

Sharma, Anupama - Kukreja, Sumita (2013), “An Analytical Study: Relevance of Financial Inclusion for Developing Nations”, International Journal of Engineering and Science, 2(6), pp. 15-20.

Swamy, Vighneswara (2014), “Financial Inclusion, Gender Dimension, and Economic Impact on Poor Households”, World Development, 56, pp. 1-15.

Terzi, Nuray (2015), “Financial Inclusion and Turkey”, Academic Journal of Interdisciplinary Studies, 4(1 S2), pp. 269-276.

Tuesta, David - Sorensen, Gloria - Haring, Adriana - Cámara, Noelia (2015), "Financial Inclusion and Its Determinants: The Argentine Case", BBVA, Research Paper, 15 (03), pp. 1-28.

Yorulmaz, Recep (2013), “Construction of a Regional Financial Inclusion Index in Turkey", Journal of BRSA Banking and Financial Markets, 7(1), pp. 79-101.

\section{Internet Kaynakları}

https://www.fo-der.org/tuzuk/, (12 Ocak 2019)

https://www.worldbank.org/en/topic/financialinclusion/overview, (29

Kasim 2019). 